\title{
Kredibilitas Pemberitaan Distribusi Vaksin Covid-19 di Indonesia
}

\author{
Anisa Suci Rahmawati*, Ferry Darmawan \\ Fakultas Ilmu Komunikasi, Universitas Islam Bandung, Indonesia. \\ *anisasuci.30@gmail.com, ferrydarmawan@gmail.com
}

\begin{abstract}
Since March 2020, news about the Covid-19 pandemic has increasingly dominated media content considering that the virus has begun to enter this country. This study focuses on media coverage of the distribution of the Covid-19 vaccine. The purpose of this study is to determine the credibility (accuracy, believability, bias and completeness) online media Detik.com and Kompas.com. This study uses a quantitative approach with content analysis method. Data collection techniques are carried out by the coding process statements or writing. Flanagin and Metzger's credibility theory was used with the object of research being the credibility of the Covid-19 vaccine distribution news in the online media Detik.com and Kompas.com December 2020 - February 2021 edition. The results of the study stated that the news published by Kompas.com on the believability dimension received $21 \%$ opinion and $93 \%$ transparency. Dimension accuracy is 100\% according to the title, $73 \%$ there is a writing error, and $43 \%$ is the suitability of the photo. The bias dimension is $53 \%$ cover both sides and the completeness dimension is $80 \%$ completeness $5 \mathrm{~W}+1 \mathrm{H}$. For news published by Detik.com on the believability dimension, it gets $18 \%$ opinion and $87 \%$ transparency. Dimension accuracy is $100 \%$ according to the title, $47 \%$ there are writing errors, and $88 \%$ is the suitability of the photo. The bias dimension is $33 \%$ cover both sides and the completeness dimension is $100 \%$ completeness $5 \mathrm{~W}+1 \mathrm{H}$. Based on the four dimensions, news about the distribution of the Covid-19 vaccine in Indonesia published by Kompas.com and Detik.com did not all meet the dimensions of credibility.
\end{abstract}

Keywords: Believability, Accuracy, Bias, Completeness.

Abstrak. Semenjak bulan Maret 2020 pemberitaan seputar pandemi Covid-19 semakin mendominasi isi media mengingat virus tersebut mulai memasuki negeri ini. Penelitian ini berfokus pada pemberitaan media mengenai distribusi vaksin Covid-19. Tujuan penelitian ini adalah untuk mengetahui kredibilitas (accuracy, believability, bias dan completeness) media online Detik.com dan Kompas.com. Penelitian ini menggunakan pendekatan kuantitatif dengan metode analisis isi. Teknik pengumpulan data dilakukan dengan cara proses coding atau menyandi pernyataan atau penulisan. Untuk membedah penelitian ini digunakan teori kredibilitas Flanagin dan Metzger dengan objek penelitian kredibilitas pemberitaan distribusi vaksin Covid-19 di media online Detik.com dan Kompas.com edisi Desember 2020 - Februari 2021. Hasil penelitian menyatakan berita yang dimuat Kompas.com pada dimensi believability mendapatkan $21 \%$ opinitative dan $93 \%$ transparansi. Dimensi accuracy $100 \%$ kesesuaian judul, $73 \%$ ada kesalahan penulisan, dan $43 \%$ kesesuaian foto. Dimensi bias 53\% cover both sides dan dimensi completeness $80 \%$ kelengkapan $5 \mathrm{~W}+1 \mathrm{H}$. Untuk berita yang dimuat Detik.com pada dimensi believability mendapatkan $18 \%$ opinitative dan $87 \%$ transparansi. Dimensi accuracy 100\% kesesuaian judul, 47\% ada kesalahan penulisan, dan $88 \%$ kesesuaian foto. Dimensi bias 33\% cover both sides dan dimensi completeness 100\% kelengkapan $5 \mathrm{~W}+1 \mathrm{H}$. Berdasarkan keempat dimensi, berita mengenai distribusi vaksin Covid-19 di Indonesia yang dimuat Kompas.com dan Detik.com belum semua memenuhi dimensi dalam kredibilitas.

Kata Kunci: Believability, Accuracy, Bias, Completeness. 


\section{A. Pendahuluan}

Informasi menjadi kebutuhan masyarakat terutama di era modern saat ini. Perkembangan teknologi dan informasi turut mempengaruhi perubahan arus informasi yang semakin cepat. Kehidupan masyarakat modern yang semakin dinamis menuntut industri media untuk menyediakan kebutuhan informasi yang dapat mengikuti perkembangan zaman. Hal tersebut yang mendasari terjadinya peralihan dari media konvensional ke media digital.

Memenuhi kebutuhan akan informasi yang cepat, media online menjadi pilihan masyarakat dalam mengakses informasi. Media online memiliki 10 karakteristik yang diantaranya adalah kecepatan dan aktualitas yang berisi informasi terbaru dengan kemudahan dan kecepatan penyajian sehingga langsung dapat diakses oleh masyarakat (Syamsul M. Romli, 2018). Meskipun begitu dua karakteristik tersebut juga dapat menjadi kelemahan dari media online mengingat semakin singkatnya proses pengolahan infomasi yang dapat mengurangi tingkat akurasi berita sehingga memengaruhi kredibilitas pemberitaan.

Salah satu penelitian yang dilakukan oleh Pew Research Center (2004) menyatakan bahwa sebagian besar wartawan yang terlibat dalam penelitian tersebut menyatakan bahwa internet telah meningkatkan jumlah informasi yang keliru (Syamsul M. Romli, 2018:37). Tentu hal ini dirasa ironi mengingat saat ini media online yang berbasis internet mulai menjadi arus utama masyarakat dalam mendapat infomasi.

Kredibilitas Media (Media Credibility) merupakan tolak ukur unsur kepercayaan pemberitaan dalam sebuah media. Sebuah pemberitaan dikatakan kredibel yaitu ketika adanya media online yang memperhatikan aktualitas dan akurasi (Canggi.2014:12).

Kredibilitas media harus memerhatikan konsistensi dan dapat dipercaya, akurasi pemberitaan yang jelas, tidak bias, keberimbangan berita, dan memuat unsur $5 \mathrm{~W}+1 \mathrm{H}$ yang merupakan kelengkapan berita (Flanagin\&Metgezer 2000:521). Menurut mereka pada realitanya seorang jurnalis online terkadang langsung mengunggah berita yang dimilikinya untuk kecepatan penyebaran informasi. Sedangkan komunikan akan lebih mungkin untuk diyakinkan ketika sumber medianya kredibel atau dapat dipercaya (Umeogu, 2012:112)

Penilaian isi sebuah media dapat ditentukan oleh khalayak sebagai penerima informasi. Oleh karena itu untuk mengetahui kredibilitas pemberitaan dari media online ini peneliti menggunakan kredibilitas Flanagin dan Metzger yang terbagi menjadi empat dimensi yaitu, believability atau kepercayaan, accuracy atau akurasi, bias, dan completeness atau kelengkapan (Flanagin dan Metgezer, 2000:522).

Informasi menjadi kebutuhan masyarakat terutama di era modern saat ini. Perkembangan teknologi dan informasi turut mempengaruhi perubahan arus informasi yang semakin cepat. Kehidupan masyarakat modern yang semakin dinamis menuntut industri media untuk menyediakan kebutuhan informasi yang dapat mengikuti perkembangan zaman. Hal tersebut yang mendasari terjadinya peralihan dari media konvensional ke media digital.

Memenuhi kebutuhan akan informasi yang cepat, media online menjadi pilihan masyarakat dalam mengakses informasi. Media online memiliki 10 karakteristik yang diantaranya adalah kecepatan dan aktualitas yang berisi informasi terbaru dengan kemudahan dan kecepatan penyajian sehingga langsung dapat diakses oleh masyarakat (Syamsul M. Romli, 2018). Meskipun begitu dua karakteristik tersebut juga dapat menjadi kelemahan dari media online mengingat semakin singkatnya proses pengolahan infomasi yang dapat mengurangi tingkat akurasi berita sehingga memengaruhi kredibilitas pemberitaan.

Salah satu penelitian yang dilakukan oleh Pew Research Center (2004) menyatakan bahwa sebagian besar wartawan yang terlibat dalam penelitian tersebut menyatakan bahwa internet telah meningkatkan jumlah informasi yang keliru (Syamsul M. Romli, 2018:37). Tentu hal ini dirasa ironi mengingat saat ini media online yang berbasis internet mulai menjadi arus utama masyarakat dalam mendapat infomasi.

Kredibilitas Media (Media Credibility) merupakan tolak ukur unsur kepercayaan pemberitaan dalam sebuah media. Sebuah pemberitaan dikatakan kredibel yaitu ketika adanya media online yang memperhatikan aktualitas dan akurasi (Canggi.2014:12).

Kredibilitas media harus memerhatikan konsistensi dan dapat dipercaya, akurasi pemberitaan yang jelas, tidak bias, keberimbangan berita, dan memuat unsur $5 \mathrm{~W}+1 \mathrm{H}$ yang 
merupakan kelengkapan berita (Flanagin\&Metgezer 2000:521). Menurut mereka pada realitanya seorang jurnalis online terkadang langsung mengunggah berita yang dimilikinya untuk kecepatan penyebaran informasi. Sedangkan komunikan akan lebih mungkin untuk diyakinkan ketika sumber medianya kredibel atau dapat dipercaya (Umeogu, 2012:112)

Penilaian isi sebuah media dapat ditentukan oleh khalayak sebagai penerima informasi. Oleh karena itu untuk mengetahui kredibilitas pemberitaan dari media online ini peneliti menggunakan kredibilitas Flanagin dan Metzger yang terbagi menjadi empat dimensi yaitu, believability atau kepercayaan, accuracy atau akurasi, bias, dan completeness atau kelengkapan (Flanagin dan Metgezer, 2000:522).

Situs media online yang sering dikunjungi di Indonesia salah satunya adalah Kompas.com. berdasarkan situs Alexa.com (diakses pada 3 April 2021) terdapat daftar peringkat situs teratas di Indonesia berdasarkan banyaknya traffic atau pengunjung dari situs tersebut. Kompas.com berada pada peringkat kelima situs yang sering diakses dan menduduki posisi ke 84 jika dalam keterlibatan internet global. Media Kompas.com menjadi salah satu pionir media online di Indonesia yang mulai menggunakan internet sebagai penyebaran informasinya sejak tahun 1995 yang mulanya bernama Kompas Online dengan alamat Kompas.co.id.

Dilansir laman situs Kompas.com awal mula Kompas Online hadir untuk memenuhi kebutuhan informasi di tempat-tempat yang tidak terjangkau oleh jaringan distribusi Kompas, agar masyarakat Indonesia terutama bagian timur maupun diluar Indonesia dapat mengakses dan menikmati konten pemberitaan Kompas. Dalam situs tersebut juga menyebutkan bahwa media dengan tagline Jernih Melihat Dunia ini pada tahun 2008 melakukan rebranding dengan pergantian nama menjadi Kompas.com dengan menambah produktivitas suguhan berita bagi para pembacanya.

Selain itu, Detik.com juga menjadi sorotan media yang sering diakses menurut Alexa.com (diakses pada 3 April 2021). Berbeda satu posisi dengan Kompas.com, Detik.com menduduki posisi keenam dalam peringkat situs Alexa Top Sites in Indonesia dan menduduki posisi 100 jika dalam keterlibatan internet global. Cepatnya arus pemberitaan Detik.com menjadikan situsnya banyak diakses di Indonesia. Dilansir laman situs Wikipedia media ini mulai menggunakan beroprerasi secara daring sejak tahun 1998 dan didirikan oleh empat orang sebelum akhirnya kepemilikannya diakusisi oleh CT Corp pada tahun 2011.

Bedasarkan pengamatan yang dilakukan peneliti Kompas.com telah memuat 274 pemberitaan dan Detik.com memuat 263 pemberitaan terkait distribusi vaksin Covid-19 yang terdiri dari kedatangan vaksin, proses perizinan, proses distribusi ke setiap provinsi hingga sampai pada para penerima vaksin, tehitung sejak bulan Desember 2020 hingga Februari 2021. Berdasarkan pemaparan tersebut peneliti merasa tertarik untuk meneliti kredibilitas pemberitaan yang disajikan oleh dua media yang memiliki tingkat pengakses yang tinggi di Indonesia.

Berdasarkan latar belakang yang telah dipaparkan, penelitian ini bertujuan untuk:

1. Untuk menganalisis kredibilitas believability pemberitaan distribusi vaksin Covid-19 di Indonesia pada media online Kompas.com dan Detik.com.

2. Untuk menganalisis kredibilitas accuracy pemberitaan distribusi vaksin Covid-19 di Indonesia pada media online Kompas.com dan Detik.com.

3. Untuk menganalisis kredibilitas bias pemberitaan distribusi vaksin Covid-19 di Indonesia pada media online Kompas.com dan Detik.com.

4. Untuk menganalisis kredibilitas completeness pemberitaan distribusi vaksin Covid-19 di Indonesia pada media online Kompas.com dan Detik.com.

\section{B. Metodologi Penelitian}

Komunikasi massa adalah pembuatan (pesan) dan penyebaran yang menggunakan teknologi lembaga dari arus pesan yang berkelanjutan serta berjaringan luas dan dimiliki oleh masyarakat (Gebner,1967). . Media online secara umum yaitu segala jenis media yang diakses menggunakan internet dan dapat berupa teks, foto, video dan suara (Antow, 2016).

Berita (news) adalah laporan mengenai suatu peristiwa atau kejadian yang terbaru (aktual); laporan mengenai fakta-fakta yang aktual, menarik perhatian, dinilai penting, atau luar 
biasa. Pelaporan mengenai sebuah kejadian penting atau sebuah pendapat yang menarik untuk khalayak luas yang disebarluaskan oleh media massa merupakan pengertian dari berita menurut (Jani Yosef, 2009:22). Dalam buku perception of Internet Information Credibility Flanagin \& Metzger mengemukakan faktor kredibilitas yang terdiri dari empat dimensi yaitu believability, accuracy, bias, compleness (Flanagin \& Metzger, 2000:516)

Penelitian ini menggunakan pendekatan kuantitatif yang merujuk pada paradigma positivistik. Penelitian kuantitatif adalah penelitian yang memiliki struktur dan data yang bersifat kuantitatif agar bisa dibuat lebih umum (Ansori, 2020:14). Penelitian dilakukan dengan metode analisis isi (Content Analysis) yang merupakan teknik mengumpulkan dan menganalisis isi teks. Dengan pengambilan sampel secara sampling purposif peneliti mengambil sampel pemberitaan yang terkait dengan kedatangan vaksin, tantangan distribusi, waktu distribusi, dan penerimaan vaksin. Dari empat kategori tersebut peneliti hanya memilih straight news dengan jangka waktu Desember 2020 - Desember 2021. Teknik pengumpulan data dilakukan dengan cara proses coding atau menyandi pernyataan atau penulisan. Untuk membedah penelitian ini digunakan teori kredibilitas Flanagin dan Metzger dengan objek penelitian kredibilitas pemberitaan distribusi vaksin Covid-19 di media online Detik.com dan Kompas.com edisi Desember 2020 - Februari 2021.

Tabel 1. Sampel

\begin{tabular}{|c|c|}
\hline Media & Judul \\
\hline \multirow{6}{*}{ Kompas.com } & $\begin{array}{l}\text { 1,2 Juta Dosis Vaksin Covid-19 Buatan Sinovac } \\
\text { Tiba di Indonesia. }(06 / 12 / 2020)\end{array}$ \\
\hline & $\begin{array}{l}\text { Vaksin Covid-19 Diperkirakan Mulai Bisa } \\
\text { Diberikan Februari 2021. (12/12/2020) }\end{array}$ \\
\hline & $\begin{array}{ll}\text { Kemenkes: } & \text { Kondisi Geografis Indonesia Jadi } \\
\text { Kendala } & \text { Distribusi } \text { Vaksin Covid-19. } \\
(14 / 12 / 2020) & \end{array}$ \\
\hline & $\begin{array}{l}\text { Kelompok Prioritas Penerima Vaksin Covid-19 } \\
\text { Menurut Peraturan Menkes. (24/12/2020) }\end{array}$ \\
\hline & $\begin{array}{l}\text { Vaksin Covid-19 Sinovac Mulai Didistribusikan } \\
\text { ke } 34 \text { Provinsi. }(03 / 01 / 2021)\end{array}$ \\
\hline & $\begin{array}{l}\text { Kemenkes: } 18 \text { Juta Dosis Vaksin Covid-19 Akan } \\
\text { Distribusikan untuk Vaksinasi Tahap Dua. } \\
(17 / 02 / 2021)\end{array}$ \\
\hline \multirow{4}{*}{ Detik.com } & $\begin{array}{l}\text { Dibawa Pesawat Boeing 777-300ER, Vaksin } \\
\text { COVID-19 Tiba di RI. (06/12/2020) }\end{array}$ \\
\hline & $\begin{array}{l}\text { Ini Kelompok Prioritas Penerima di Permenkes } \\
\text { Pelaksanaan Vaksinasi COVID-19. (24/12/2020) }\end{array}$ \\
\hline & $\begin{array}{l}\text { Jokowi Paparkan Target Distribusi } \\
\text { Vaksin Corona ke Daerah Hingga } \\
\text { (06/01/2021) }\end{array}$ \\
\hline & $\begin{array}{l}4 \text { Juta Dosis Vaksin Disuntikkan Februari, } \\
\text { Begini Distribusinya. (23/01/2021) }\end{array}$ \\
\hline
\end{tabular}




\begin{tabular}{|l|l|}
\cline { 2 - 2 } & $\begin{array}{l}\text { Bos Bio Farma Ungkap Pentingnya Pengawasan } \\
\text { Distribusi Vaksin. (29/01/2021) }\end{array}$ \\
\cline { 2 - 2 } $\begin{array}{l}\text { 7,5 Juta Vaksin Bio Farma Siap Disebar Bulan } \\
\text { Ini. (16/02/2021) }\end{array}$ \\
\hline
\end{tabular}

\section{Hasil Penelitian dan Pembahasan}

Tingkat Kredibilitas Pemberitaan Distribusi Vaksin Covid-19 di Indonesia pada Media Online Kompas.com dan Detik.com dalam Dimensi Believability

Dimensi ini mengukur tingkat kepercayaan dalam berita. Pada dimensi believability peneliti membagi menjadi dua konstruksi kategori yaitu opinitative dan transparansi. Menggunakan konstruksi kategori ini peneliti dapat mengetahui berita yang dimuat Kompas.com dan Detik.com mengenai distribusi vaksin Covid-19 di Indonesia apakah terdapat unsur opinitative dan mengetahui transparansinya. Pada dimensi ini satuan unit analisis yang digunakan adalah paragraf. Sebuah paragraf dikatakan opinitative jika mengandung peristiwa atau tanggapan yang diberitakan bersifat subjektif atau didramatisasi, juga terdapat opini wartawan. Sedangkan paragraf dikatakan transparansi ketika adanya transparansi terhadap sumber berita. Dalam hal ini sumber berita disajikan dengan jelas tidak ditutup-tutupi untuk kepentingan tertentu. Sebuah berita akan dikatakan believable ketika transparansi sumber berita menjadi perioritas utama yang harus terpenuhi (Widodo, 2012).

Bedasarkan hasil penelitian dari keenam berita yang dimuat Kompas.com mengenai distribusi vaksin Covid-19 di Indonesia persentase yang didapat untuk dimensi believability sebesar $21 \%$ untuk paragraf opinitative dan $93 \%$ untuk paragraf transparansi. Hal ini berarti berita yang dimuat Kompas.com mengenai distribusi vaksin Covid-19 di Indonesia untuk konstruksi kategori opinitative tergolong sangat rendah maka berita yang disajikan tidak banyak terkandung paragraf yang subjektif, didramatisasi, atau terdapat opini wartawan. Berita dapat dikatakan kredibel jika pesan yang disampaikan sesuai fakta (Angkawijaya, 2017). Sedangkan untuk konstruksi kategori transparansi tergolong sangat tinggi, yang menunjukan berita yang disajikan sudah menyebutkan sumber berita dengan jelas dan tidak menutup-nutupi demi kepentingan tertentu.

Hasil penelitian media Detik.com dari keenam berita mengenai distribusi vaksin Covid19 di Indonesia pada dimensi believability sebesar 18\% untuk paragraf opinitative yang menunjukan berita yang dimuat hanya sedikit terdapat paragraf yang subjektif, didramatisasi atau mengandung opini wartawan. Untuk paragraf transparansi Detik.com memiliki hasil persentasi sangat tinggi yaitu $87 \%$ yang meunjukan berita yang dimuat sudah menerapkan transparansi. Suatu berita dapat diliat kredibilitasnya dari hasil sumber informasi yang digunakan berita tersebut (Flanagin dan Metzger, 200, p.521). Pemberitaan distribusi vaksin Covid-19 di Indonesia merupakan sumber informasi bagi masyarakat ditengah pandemi saaat ini maka berita yang dikonsumsi harus terjamin sumbernya.

Tingkat Kredibilitas Pemberitaan Distribusi Vaksin Covid-19 di Indonesia pada Media Online Kompas.com dan Detik.com dalam Dimensi Accuracy

Berita yang dimuat media harus melawati fase verifikasi agar berita yang disajikan akurat. Flangin dan Metzger pernah menjelaskan bahwa berita yang disebarkan media konvesional harus melewati proses verifikasi sebelum disebarluaskan (Flanagin dan Metzger, 200, p.521). Dimensi accuracy ini dibagi kedalam tiga konstruksi katergori yaitu kesesuaian judul, kesalahan penulisan dan kesesuaian foto. Judul yang tidak sesuai dalam berita dapat membuat pembaca bingung bahkan merasa tertipu jika judul yang dipakai tidak sesuai atau clickbait. Dengan dimensi ini pula peneliti dapat mengukur kesalahan penulisan dan kesesuaian foto yang terkandung dalam berita. Kesalahan penulisan dan ketidaksesuaian foto dalam sebuah berita menunjukan kurangnya verifikasi dari wartawan dan editor dari media tersebut. Pada dimensi ini digunakan satuan unit analisis berita. 
Hasil penelitian menunjukan untuk konstruksi kategori kesesuaian judul dari 6 berita yang dimuat Kompas.com dan 6 berita yang dimuat Detik.com keduanya memiliki jumlah persetase yang sama yaitu $100 \%$ dengan kata lain kedua media ini sudah menyajikan judul yang sesuai bagi pemberitaan distribusi vaksin Covid-19 di Indonesia. Selanjutnya konstruksi kategori kesalahan penulisan Kompas.com memiliki persentase 73\%. Dengan tingginya persentase tersebut berita yang dimuat Kompas.com belum memperhatikan akurasi kesalahan penulisan. Untuk konstruksi kategori kesesuaian foto mendapatkan persetase kurang tinggi yaitu $43 \%$. Dengan begitu berita yang dimuat Kompas.com masih banyak yang belum dilengkapi dengan foto berita yang sesuai.

Berita yang dimuat Detik.com memiliki persentase kesalahan penulisan yakni $47 \%$ yang tergolong kurang tinggi. Hal ini membuktikan bahwa berita yang dimuat Detik.com sudah memerhatikan akurasi kesalahan penulisan sebelum disebarluaskan. Terakhir untuk konstruksi kategori kesesuaian foto, media Detik.com memiliki persentase sangat tinggi yaitu $88 \%$ yang menunjukan berita yang dimuat sudah dilengkapi dengan foto berita yang sesuai.

Kesalahan penulisan dapat terjadi karena kurang telitinya proses verifikasi berita sebelum disebarluaskan, baik dari wartawan maupun editor media. Berbagai istilah dalam bahasa asing di pemberitaan distribusi vaksin Covid-19 ini sering menjadi kesalahan dalam penulisannya. Selain itu foto jurnalisitk yang menjadi pelengkap berita harus memiliki kesinambungan dengan berita yang disajikan. Dalam hal ini Kompa.com dinilai lebih sering menyajikan berita dengan foto yang kurang sesuai. Hal ini dapat disebabkan oleh kurangnya perhatian wartawan dalam memilih foto berita yang digunakan.

Tingkat Kredibilitas Pemberitaan Distribusi Vaksin Covid-19 di Indonesia pada Media Online Kompas.com dan Detik.com dalam Dimensi Bias

Dimensi bias diturunkan pada konstruksi kategori cover both sides. Dalam pembuatan berita unsur cover both sides menjadi hal yang penting karena berkaitan dengan keberimbangan berita. Dengan memperhatikan cover both sides berita yang dihasilkan dapat netral atau tidak berpihak pada satu pihak atau organisasi tertentu. Pada dimensi ini digunakan satuan unit analisis berita.

Berdasarkan hasil penelitian media Kompas.com memiliki persentase kurang tinggi yaitu 53\% meskipun begitu Detik.com tidak lebih baik dari Kompas.com karena memiliki persentase sangat kurang tinggi yakni 33\%. Kedua media ini tidak memenuhi penilaian cover both sides. Semestinya keberadaan cover both sides diperhatikan para media dalam membuat produknya. Seperti yang dikatakan Eriyanto bahwa keberimbangan berita merupakan pemberitaan yang tidak memisahkan atau mengambil sisi tertentu, jadi pemberitakan disajikan utuh dari berbagai sisi (Eriyanto,2011:195).

Berdasarkan pengamatan peneliti dari 12 berita mengenai distribusi vaksin Covid-19 di Indonesia kedua media dalam menyajikan beritanya seringkali hanya memberitakan dari satu sisi. Kedua media jarang menyajikan lebih dari satu narasumber sehingga padangan yang yang diberitakan hanya satu sisi atau tidak ada komentar pembanding yang akan menambah sisi pemberitaan. Hal tersebut berkaitan dengan penyajian fakta dalam berita yang harus menghadirkan sumber yang relevan, baik dengan pernyataan setuju maupun tidak setuju. Berita yang cover both sides dapat menghilangkan kecenderungan media dalam memberikan kritik atau pujian yang spesifik pada salah satu pihak atau organisasi. Kedua media ini dinilai tidak kredibel dari dimensi bias.

\section{Tingkat Kredibilitas Pemberitaan Distribusi Vaksin Covid-19 di Indonesia pada Media Online Kompas.com dan Detik.com dalam Dimensi Completeness}

Dimensi completeness digunakan peneliti untuk melihat kelengkapan $5 \mathrm{~W}+1 \mathrm{H}$ dari masingmasing enam berita mengenai distribusi vaksin Covid-19 yang dimuat media Kompas.com dan Detik.com. Pada dimensi ini digunakan satuan unit analisis berita. Berdasarkan hasil penelitian media Detik.com memiliki persentase sangat tinggi yakni $100 \%$. Begitu juga dengan Kompas.com memiliki persentase sangat tinggi yakni $80 \%$. Kedua media memiliki hasil persentase yang tinggi hal ini menunjukan keduanya sudah memperhatikan akurasi kelengkapan $5 \mathrm{~W}+1 \mathrm{H}$.

Selama negeri ini masih dilanda pandemi Covid-19 informasi mengenai vaksin sangat diperlukan masyarakat. Selain itu program vaksin Covid-19 yang sedang berjalan diberbagai 
daerah membuat pemberitaan ini berlangsung continue atau akan selalu diberitakan selama pemerintah masih menjalankan program ini. Dengan kondisi tersebut kedua media dapat menjaga pemberitaannya agar tetap memuat informasi selengkap mungkin.

\section{Kesimpulan}

Dari keempat dimensi, berita mengenai distribusi vaksin Covid-19 di Indonesia yang dimuat Kompas.com dan Detik.com belum semua memenuhi dimensi kredibilitas. Berdasarkan hal tersebut peneliti menyimpulkan dalam beberapa poin sebagai berikut:

1. Kredibilitas berita distribusi vaksin Covid-19 di Indonesia pada dimensi believability konstruksi kategori opinitative berita yang dimuat media Kompas.com sebesar 21\% dan Detik.com sebesar $18 \%$. Hal ini menunjukan berita yang dimuat Kompas.com dan Detik.com hanya sedikit mengandung paragraf opinitative. Konstruksi kategori transparansi, berita yang dimuat media Kompas.com dengan persentase $93 \%$ dan Detik.com dengan persentase $87 \%$, dengan begitu kedua media sudah menerapkan transparansi dalam beritanya.

2. Kredibilitas berita distribusi vaksin Covid-19 di Indonesia pada dimensi accuracy, berita yang dimuat media Kompas.com 100\% untuk kesesuaian judul, $73 \%$ untuk adanya kesalahan penulisan, dan $43 \%$ untuk kesesuaian foto, dengan begitu berita yang dimuat Kompas.com belum memenuhi akurasi kesalahan penulisan dan keseuaian foto. Media Detik.com mendapatkan persentase $100 \%$ untuk kesesuaian judul, $47 \%$ untuk adanya kesalahan penulisan, $80 \%$ untuk kesesuaian foto, dengan begitu berita yang dimuat Detik.com sudah cukup memenuhi akurasi ketiga konstruksi kategori.

3. Kredibilitas berita distribusi vaksin Covid-19 di Indonesia pada dimensi bias konstruksi kategori cover both side berita yang dimuat media Kompas.com dan Detik.com samasama belum memenuhi cover both side dalam pemberitaanya karena hanya memiliki persentase 53\% untuk Kompas dan 33\% untuk Detik.com.

4. Kredibilitas berita distribusi vaksin Covid-19 di Indonesia pada dimensi completeness konstruksi kategori $5 \mathrm{~W}+1 \mathrm{H}$ berita yang dimuat media Kompas.com dan Detik.com sudah kredibel dengan persentase 80\% media Kompas.com dan 100\% media Detik.com. Dapat disimpulkan bahwa media yang dianggap kredibel dan banyak diakses masyarakat ternyata dalam pemberitaannya masih memuat berita yang belum memenuhi dimensi kredibilitas secara keseluruhan. Pemberitaan yang masih mengandung kesalahan penulisan, subjektivitas wartawan atau media, dan belum menyajikan berita secara berimbang masih dapat kita temukan dan bisa saja menjadi sumber utama informasi yang biasa kita konsumsi. Pihak media dan pembaca memiliki peran masing-masing dalam hal ini. Pihak media harus merasa lebih bertanggung jawab atas kredibilitas berita yang disajikan dengan memerhatikan proses verifikasi. Sedangkan sebagai pembaca kita memiliki tanggung jawab penuh atas infomasi yang kita pilih untuk dikonsumsi.

Penelitian yang terkait dengan kredibilitas dapat dilakukan tidak hanya meneliti pemberitaannya. Penelitian kredibilitas dapat digunakan untuk meneliti medianya dengan bentuk apapun baik cetak maupun digital atau bahkan meneliti kredibilitas wartawan yang terlibat didalam media tersebut. Selain itu menentukan topik pemberitaan yang sedang hangat atau dibutuhkan masyarakat dapat menambah kebermanfaatkan penelitian. Ruang lingkup penelitian juga dapat diperluas dengan meneliti lebih dari satu rubrik dalam suatu media. Meneliti sebuah media selain menggunakan analisis isi dapat juga menggunakan metode lain seperti analisis framing atau lainnya yang dapat menambah literatur mengenai kredibilitas pemberitaan dari suatu media.

\section{Acknowledge}

Peneliti mengucapkan terimakasih kepada seluruh pihak terkait terutama kepada Bapak Dr. Ferry Darmawan, S. Sos., M. Ds yang telah membimbing dan memberikan dukungan bagi peneliti sehingga penelitian ini dapat diselesaikan. 
114 | Anisa Suci Rahmawati, et al.

\section{Daftar Pustaka}

[1] Adyaksa, V. (2021). Data Kominfo Sebut Sebaran Hoaks Seputar Vaksin Covid-19 Terbanyak di Facebook. 3-4. https://www.liputan6.com/tekno/read/2854713/survei-mediasosial-jadi-sumber-utama-penyebaran-hoax

[2] Ansori, M. (2020). Metode Penelitian Kuantitatif Edisi 2. Airlangga University Press.

[3] Ode, C. A. A. (2014). Kredibilitas Pemberitaan Pada Portal Berita Online Kompas.Com. In Skripsi.

[4] Syamsul M. Romli, A. (2018). Jurnalistik Online: Panduan Mengelola Media Online - Asep Syamsul M. Romli - Google Books.

[5] Kautsar, M. N. A. (2016). Kredibilitas Pemberitaan Portal detik.com (Analisis Isi Portal Berita Online). Journal of Chemical Information and Modeling, 6(2), 1-91.

[6] Hamdi, A. S., \& Bahruddin, E. (2015). Metode penelitian kuantitatif aplikasi dalam pendidikan. Deepublish.

[7] Wien, C. (2005). Defining Objectivity within Journalism. Nordicom Review, 26(2), 3-15. https://doi.org/10.1515/nor-2017-0255

[8] Widodo, R. (2012). Kredibilitas Pemberitaan Pada Portal Berita Online Vivanews . Com. Jurnal Penelitian Jurusan Ilmu Komunikasi Fakultas Ilmu Sosial Dan Ilmu Politik Universitas Diponegoro. 